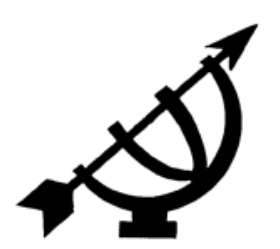

\title{
Professor Bennie van der Walt: a bridge between white Afrikaners and black Africans
}

\author{
Y. Turaki \\ Department of Theology \& Social Ethics \\ Jos ECWA Theological Seminary \\ NIGERIA \\ E-mail: byturaki@yahoo.com
}

\begin{abstract}
Professor Bennie van der Walt: a bridge between white Afrikaners and black Africans
\end{abstract}

This article honours Professor Bennie van der Walt as a bridge builder between white Afrikaners and black Africans as well as a renowned Christian scholar. Historical Western colonialism in South Africa divided its citizens against each other by means of white racism and apartheid. The whites in general were pitched against the blacks on the basis of white racism and its doctrine of apartheid. This doctrine of separation of races kept the white Afrikaners from the Bantu Africans. However, apartheid as a form of political, social, cultural and religious racism is now history in South Africa. The role which Professor Van der Walt played in bridging the gap between this racial divide is highly commendable and needs to be acknowledged and appreciated, hence the primary objective of this article in honour of his 71st birthday. Furthermore, the article discusses the immense contributions of Professor Bennie van der Walt to Christian scholarship in Africa.

\section{Opsomming}

\section{Professor Bennie van der Walt: 'n brugbouer tussen wit Afrikaners en swart Afrikane}

Hierdie artikel bring eer aan professor Bennie van der Walt as brugbouer tussen wit Afrikaners en swart Afrikane, en as gerespekteerde Christelike akademikus. Die geskiedenis van Westerse kolonialisme het Suid-Afrika se burgers verdeel en 
teen mekaar gedraai deur middel van wit rassisme en die leerstelling van apartheid. Hierdie leerstelling van rasseverdeling het wit Afrikaners weggehou van swart Afrikane. Apartheid as vorm van politieke, sosiale, kulturele en religieuse rassisme is egter nou deel van Suid-Afrika se geskiedenis. Die rol wat professor Van der Walt gespeel het om die gaping tussen die rasgebaseerde verdeeldheid te oorbrug, is hoogs prysenswaardig en behoort erken en waardeer te word - vandaar die primêre doelwit van hierdie artikel ter ere van sy $71 \mathrm{e}$ verjaardag. Die artikel bespreek ook professor Bennie van der Walt se ontsaglike bydrae tot Christelike wetenskap in Afrika.

\section{Introduction}

I write this article to contribute to this special issue of Koers in honour of Professor Bennie van der Walt, a dear friend of mine. I join my colleagues in "celebrating Professor Van der Walt's exceptional philosophical legacy". I structured my style of writing to meet this very objective. I will be more formal than scholarly as my comments and opinions about Professor Bennie van der Walt simply add to what others are saying in this volume. My primary goal is to highlight his immense contribution to the legacy of Christianity in Africa. Firstly, Professor Van der Walt was a bridge builder between white Afrikaners and black Africans. Secondly, he made substantial contributions to Christian scholarship in Africa. The article is focused on describing how Professor Van der Walt is indeed a bridge builder, on the one hand, and a renowned Christian scholar, on the other hand. The article is written from a personal perspective describing how I came to know him as a person, a friend, and an erudite scholar. I do not have an exhaustive knowledge of his person or his corpus of scholarship. For this reason, I will simply write about a dear friend and say a few things about his personal life and writings which I have personally come to know. In order to honour his 71st birthday, I will be highly selective in the things I write about him and his works. The aim is not to give an in-depth analysis of the works of Professor Bennie van der Walt, but to focus on his person and his major contribution to Christian scholarship in Africa. I limit myself to some comments and opinions about Professor Van der Walt and his works.

\section{The man: Professor Bennie van der Walt}

I first met Professor Bennie van der Walt in January 1989 at the writer's workshop for the Christian Literature Committee for Africa (CLCA) at Harare, Zimbabwe. The workshop was organised by the 
Institute for Reformational Studies (IRS) of the Potchefstroom University for Christian Higher Education and the International Association for Reformed Faith and Action (IRFA). The Institute was then headed by Professor Van der Walt. Subsequently, I was invited by Professor Van der Walt to different conferences organised by the IRS in 1989, 1991 and 1992 (Turaki, 1999:vi). We also regularly saw each other at various international meetings outside of Africa. In addition to these international conferences, we communicated by exchanging publications. Whenever we had the opportunity of meeting again, we usually had deep and engaging discussions about Christianity in Africa, especially in its present state and its future prospects or problems (Turaki, 1999:vi). During the era of apartheid, we discussed its impact, especially on the rest of Africa. As a followup to this, Professor Van der Walt requested that I write something on apartheid. He published my article as a monograph of the IRS, An African response to the question of apartheid (Turaki, 1992).

After the fall of apartheid, we turned our attention to the relationship between Christianity and African Traditional Religion and cultures. On many occasions, Professor Van der Walt encouraged me to write a book on this subject. Through his support, the IRS published my book, Christianity and African gods: a method in theology (Turaki, 1999). This is what Professor Van der Walt said about the publication of this book:

Quite a number of books have been published in this CLCA project, but this one is the most important of them all. Because I have to take compulsory retirement at the age of sixty at the end of this year, I regard this book as a special blessing from the Lord - without it my mission as director of the IRS would not have been completed. (Turaki, 1999:vi-vii.)

Our friendship grew over the years and we have had opportunities to visit and stay in each other's homes for a few days at a time. It was during these homely situations that I personally got to know Professor Van der Walt as a man of deep convictions, Christian faith and prayer. His love for the Word of God, the Bible and his commitment to these convictions as the foundation of both his theology and philosophy is uncompromising. I saw a man consumed by a great desire for right Christian thinking and living through an integral and comprehensive Christian reformational worldview that is deeply rooted in the Bible and Christian faith (Turaki, 1999:vi). By knowing Professor Van der Walt's deep Christian and biblical roots and faith through such close encounters, I now understand why he is so consistent and persuasive in the exposition of his views in his 
Christian scholarship. He is a man who carries the burden of formulating the right Christian scholarship as a tool for transformation of both humanity and society (creation).

It is not my intention to explore the inner life of Professor Van der Walt. I leave it to others to report on this aspect of his life. I will discuss only some aspects of his background in order to give insight into who he is and the evolving nature of his Christian scholarship.

\section{Professor Van der Walt's background: apartheid and the African context}

I know that a brief history of the making of South Africa as a modern nation-state in Africa would be better presented by some of the other contributors to this volume who are more qualified than I. For this reason, I will focus on some aspects of white racism and its ideology of apartheid.

The historical question of white racism and apartheid challenged both the Christian faith and its scholarship. Professor Van der Walt gradually and systematically responded to this immediate background in South Africa and the wider African context. He faced the great challenges of white racism and apartheid, Western theological dualism and secularism, the conflict of Western and African cultures, and the search for a reformational worldview and transformational theology for Africa. These challenges transformed him into becoming a bridge builder in a divided Africa and an erudite Christian scholar. He became the man who, through personal contacts and extensive and vigorous Christian scholarship, constructed a bridge that connected white Africans to black Africans during the era of white racism and apartheid. His bridge building was done effectively through organising conferences that brought together the whites and blacks for fruitful and meaningful engagement, as well as dialogue and sharing of their experiences of white racism and apartheid, conflict of cultures, and colonial, missionary and traditional contexts of Africa.

Permit me to briefly give a separate background of white racism and apartheid in the next section, while we treat the corpus of his Christian scholarship much later.

\subsection{White racism and apartheid}

It is important that I swiftly say something about white racism and apartheid which troubled the conscience of Professor Van der Walt 
as a Christian. This understanding came from our mutual sharing of life experiences from Africa in general. My main objective is not to give an exhaustive analysis of the history of white racism and apartheid in South Africa as I am not competent to do so. I need only state its influence upon the young Bennie van der Walt as he was growing up in South Africa.

Apartheid, historically speaking, was a racial ideology, an offshoot of the white Afrikaner's nationalism in South Africa. Its historical roots go back to the British colonial legacy of the separation of races in Africa. This historically evolved racial ideology later became the greatest stumbling block and communication barrier between the whites and blacks in South Africa and to some lesser degree the whole continent of Africa which was under the domination of both European and Arab colonialism. Apartheid as a racial ideology became the focus of cultural, social, political and economic controversy, misunderstanding, misinterpretation and even misrepresentation on both sides of the divide. This racial division ran deep emotionally, religiously, culturally, politically, economically and socially in South Africa before the early 1990s (Turaki, 1992:1). Those of us who were black Africans and who saw the devastating effects of white racism and apartheid in South Africa commented variously about it.

Africans generally see apartheid as the illegitimate child of European colonialism born on African soil. For many decades, this illegitimate child has grown into becoming the most notorious bully-rag of Africa and has indeed become Africa's major concern and terror. (Turaki, 1992:2.)

Africans have many pictures about white racism and apartheid, just as others have about African tribalism and ethnocentrism. We thank God that apartheid with all its varied definitions is now history. Of course, we must not forget the principles of invariance, the persistence or continuity of authority codes of ideas or values (Baum, 1977:5-28). Sometimes values live long after the demise of the institutions that harbour them.

I have read about apartheid in books and heard about it through mass media, but to experience it personally is quite different. I have listened to both white and black South Africans tell me about their experiences of apartheid, and especially to Bennie's own story. I visited South Africa a few times before the fall of apartheid in the early 1990s. 
Prior to this, I had a school mate at Boston University in the late 1970s from South Africa who shared with me his own personal struggles with white racism and apartheid during the days of Steve Biko's Black Consciousness Movement (BCM). Professor Motlhabi Mokgethi was the General Secretary of the Student Movement of BCM who told me about their aspirations and consciousness-raising strategies against apartheid. He contributed to their publication, Essays on black theology (Motlhabi, 1972). The major thrust of his doctoral dissertation at Boston University (Motlhabi, 1980) was the development of a non-violent strategy towards apartheid using the philosophies of Ghandi, Martin Luther King, Jnr., Walter Muelder's personalism, Edgar Brightman's moral laws and the philosophy of the Black Consciousness Movement (Motlhabi, 1988).

Apartheid impacted the blacks of South Africa in three major ways: race, land and African personality/culture. It was the adverse impact of apartheid on black Africans that gripped the heart of Professor Van der Walt. As a state racial policy, the blacks in question were rendered politically and economically powerless and dehumanised. This deeper meaning and impact of apartheid gripped Professor Van der Walt's conscience. As a Christian philosopher-theologian, he was fully aware of its historical roots and conditioning, its historicalreligious unfolding and affirmation, its cultural incubation and grooming, its economic rationale and ethic, its political logic and state policy and its racial inner spirit and compelling power (Turaki, 1992:7). Professor Van der Walt engaged himself in a serious quest for a Christian scholarship that could effectively address, evaluate and critique the religious roots of apartheid. He was a student of philosophy in the tradition of Christian scholarship at the Potchefstroom University for Christian Higher Education, the Theological School of the Reformed Churches in South Africa and the Free University of Amsterdam in the Netherlands. His training in Christian philosophy and theology prepared him to address white racism and apartheid in the subsequent development of his Christian scholarship.

The religious roots of apartheid, as developed and nurtured by the Afrikaner church, is one of the most serious historical, moral, spiritual and ethical indictments on Afrikaners' Christianity. Professor Van der Walt stood his ground and refused to legitimise and affirm white racism and its ideology of apartheid. Even though it was a personal risk in a "police state" for him to break ranks with his compatriots, he openly criticised apartheid practice and probed into the moral conscience of the white Afrikaner in his tenacious holding 
on to his strong belief in apartheid (Turaki, 1992:8). I would not be able to fathom Professor Van der Walt's strength of character or measure his substantial contribution to Christian scholarship in Africa without this difficult and vexing context of apartheid with which he had to contend with. Professor Van der Walt pitched himself against his background and his own church, a situation which was capable of claiming the life of anyone who dared to be different. This strength of character is noteworthy against the powerful and pervasive influence of apartheid.

My personal visits to the Afrikaners' historical sites, monuments and listening to the re-telling of Afrikaners' history of the Boer Wars in Potchefstroom, made me realise the magnitude of the impact which such a profound historical background could have had on Professor Van der Walt. It was his response to apartheid's context that blossomed into a gigantic corpus of Christian scholarship worthy of this dedicatory volume in his honour. I hail the courage of young Bennie who defied the strangle hold of white racism and apartheid, a phenomen I describe as follows:

Apartheid was a powerful ethnocentric ideology which was capable of creating a police state, hence, it had power of indoctrination, socialization, nurturing, assimilation and coercion, suppression and oppression. Its boundaries were well defined ethnically or racially, which transcended individuality. It was a movement whose locus was not in individuality nor within a nation-state boundary of a geo-political entity but of racial exclusivity and ethnocentrism. It was an aggregate of racial conscience, pride, identity and destiny which had developed over the period of time. For this reason, it had racial power, will and being. Individuals both within and outside who sought to differ or posed a great threat to its will, destiny and mission, stand the risk of total annihilation. To differ is heresy and treason and these ones do not know the way of peace but of violence and liquidation. Individuals within the apartheid system learnt in a hard way that the language of conformity, acquiescence and coercion, suppression and oppression applied. This language had kept in bondage and silence the would-be heretics and those who would seek to differ and seek to divert from apartheid. He who sought to dismantle apartheid whether an insider or an outsider, engaged himself with a powerful force capable of inflicting mortality, of stripping one naked, and denying one of all rights. Apartheid was such a powerful enemy of justice and rights because it succeeded in capturing the heart of humanity and ultimately its conscience, 
thereby inflicting it with durable and incurable racial wounds. (Turaki, 1992:8.)

These are the words I used to describe the historical context that Professor Van der Walt came from. At our first meeting in South Africa, I was very much scared by his criticism of apartheid and the position of the Reformed Churches in South Africa. I feared for his life knowing what apartheid was capable of doing.

Professor Van der Walt struggled with white racism and apartheid. I remember during one of the international conferences, the black African folks raised objections to some of the comments in one of his pioneering works. He was gracious enough to accept some of the blind spots in his Christian scholarship and promised to revise and discard such an accidental demeanor as he never thought it to be offensive to black Africans. Certainly, people all over the world, at times do become prisoners of their past and backgrounds. Some do find it very difficult to shake off their past or background, but Professor Van der Walt in his voluminous Christian scholarship, has demonstrated the spirit of openness, appreciation and maturity in discussing even the most difficult issues like white racism and apartheid, and executing comparative studies of Western and African cultures. Because of his consistency, erudite scholarship and willingness to share his convictions and correct what is obnoxious, offensive and heretical, he is not afraid to cross traditional and cultural boundaries just to get his views across.

Historically, apartheid imprisoned and isolated the white Afrikaner from the rest of Africa. The need to set the Afrikaner free from selfimprisonment and the self-inflicted racial wounds of apartheid, urged Professor Van der Walt to take up the mandate of reaching out to black Africans. The dangers existed not only within the context of apartheid South Africa, but also loom largely in the rest of Africa, especially in relation to the devastating influence of Western dualism and secularism, on the one hand, and the devastating influence of negative African cultures, worldviews, communalism and kinship values. Hence the necessity of reaching out to the rest of Africa.

Professor Van der Walt could not be imprisoned or immobilised by white racism and apartheid. He could not be tamed by guilt and shame as some of his colleagues fell victim to white racism, apartheid and ethnocentrism. The stigma of apartheid was not a prohibita to him. His Christian scholarship in philosophy and theology have defined and clarified for him what apartheid is all about, a theological heresy and a political tool of oppression and 
subjugation. Not only did he see the alarming danger of apartheid for the church and South Africa, but across the fence, he also saw another danger rearing its head in larger Africa. This greater danger for the African church was not apartheid, but Western dualistic Christianity, secularism and African communalism and kinship values. The prophetic role of Professor Van der Walt as a Christian scholar launched him out of his immediate context in South Africa into the African continent.

His primary objective for reaching out to black Africans was not to be an apologist for apartheid or as a crusader against apartheid, but rather to correct a theological conviction of his church which had divided the unity of the Body of Christ by means of racism and apartheid. The practical life of Professor Van der Walt is a demonstration of the truth of the Bible as described in Ephesians 2. Our Lord Jesus Christ came to unite the divided humanity and to create a new messianic community or a new humanity by abolishing all walls of division or barriers. We are all one in Christ Jesus (Gal. $3: 11$ ). The church is an institution founded by our Lord as the means of uniting the divided world and the formation of a new humanity or a messianic community. Professor Van der Walt demonstrated these cardinal ecclesiastical and biblical truths practically through his physical presence among black Africans both in his own home and in the homes of black Africans in South Africa, and also across the continent of Africa during the era of apartheid. During one of my visits to his home, I was amazed to see the inventory of visitors who had spent days with his family. Most of them were black Africans. Professor Van der Walt told me about his up-bringing, especially by his mother who taught him love for black Africans. He had also passed the same principle to his children.

His reaching out to black Africans was motivated by the desire to share his Christian faith and convictions, especially the Christian reformational worldview and the philosophy of Christian higher education. He also wanted to share with all Christians in Africa the devastating influence of Western dualism and secularism. These negative Western values have not strengthened Christianity; rather, they have weakened it. The solution to Western dualism and secularism is the Biblical reformational worldview and Christian philosophy of higher education. This not only corrects Western dualism and secularism, but also the African worldviews, especially values such as communalism and some forms of culture that inhibit the socio-political and economic development of Africa. Professor Van der Walt sees his task and contribution to Christian scholarship in 
Africa as that of developing and formulating a philosophy of Christian higher education that is rooted in the biblical reformational worldview.

\section{Professor Van der Walt's burdens: his passion, vision and mission for Africa}

In this section, I am examining in brief his Christian scholarship and writings which manifest his great concern for Africa. His passion, vision and mission for Africa can be revealed in both his personality and Christian scholarship. Professor Van der Walt took it upon himself to recruit young Christian scholars in Africa like myself to join him in his vision for African Christian scholarship and Christianity. He did his work with much love, affinity, passion and obligation to Africa. My analysis of the corpus of Christian scholarship of Professor Van der Walt in this section will be very brief and cursory due to limited space. For this reason, I present some personal views and observations with regard to only a select number of themes recurring in Professor Van der Walt's writings. I intend not to be exhaustive or systematic, but to highlight only what I find important in relation to his scholarship.

\subsection{On white racism and apartheid}

Professor Van der Walt did not write as much about apartheid as he did on other subjects. He shared with me that his primary response and approach to racism and apartheid took root in his family background. He was personally involved along with his family in dealing with the practical issues of racism and apartheid in South Africa as these affected the lives of black South Africans. However, in reviewing his corpus of Christian scholarship, I came across his article on the topic of racism and apartheid (Van der Walt, 1993:2952). This article describes how he addressed the question of apartheid. He also wrote on similar subjects that deal with the vision of humanity and society from a biblical perspective. Some of these works are: Being human: a gift and a duty - on the way to a Christian view of man for Africa (Van der Walt, 1990); Responsibility, conversion, confession, forgiveness, restitution and reconciliation: six of God's requirements for a New South Africa (Van der Walt, 1996); The Bible as eye-opener on the position of women (Van der Walt, 1988a); On being human and being a Christian in Africa: communalism, socialism and communism in a struggle for an African anthropology (Van der Walt, 1988b). 
Due to lack of space, we will limit ourselves to his views on apartheid. Professor Van der Walt states: "Apartheid is an ideology, and moreover a dangerous one" (Van der Walt, 1993:30). Also:

Apartheid is an ideology, which usually comes into being in a situation of threat, is a substitution of true religion with, at its highest ideal, an all-encompassing purpose, to the attainment of which any (power) means may be used, norms adapted, sacrifices demanded, and a specific image of the enemy propagated. (Van der Walt, 1993:52.)

Apartheid, he notes, had many faces: "it is like a many-headed monster" (Van der Walt, 1993:31). He identified seven ideological components of apartheid: a nationalist ideology, a communalist ideology, a racist ideology, a security ideology, an ideology of prosperity, a revolutionary ideology, and with a religious face (Van der Walt, 1993:31-39). We have no need of elaborating on each of the forms of the apartheid ideology as it now lies in the past. To demonstrate that Professor Van der Walt attempted to deal with the question of apartheid the following should be noted. He observed that
Apartheid is not simply a political policy. It is also not simply a collection of segregational laws so that, as soon as the laws have been repealed, apartheid will also disappear. It is a stubborn ideology which causes people to view reality in a certain way. This is the foundation of the whole South African societal order. It has also led to a physical condition of unequal distribution of power and prosperity. (Van der Walt, 1993:31.)

He not only critiqued apartheid as a Christian scholar, but put his life and family at risk. "Only the people who suffered under this terrible ideology will be able to fully tell you how it dehumanized them" (Van der Walt, 1993:39). He proposed a solution for the victims of apartheid in the following words:

A South Africa freed from apartheid therefore demands economic re-structuring and the re-location of wealth as well as the means of creating wealth for those who had been impoverished by apartheid. The mere creation of a fund to help the poor is not adequate. Enormous amounts will be necessary for the backlog in housing, education, health care, supply of jobs, et cetera. (Van der Walt, 1993:46.)

Professor Van der Walt's criticism of apartheid was rooted in his biblical view of man, which he called "scriptural anthropological viewpoints" (Van der Walt, 1993:46). These biblical views form the 
basis of humane treatment of all human beings. He listed these ethical values as human equality and equal dignity, human diversity and unity, human interdependence, human (individual) responsibility, and human groups and societal relationships. These biblical and ethical values define a Christian vision of humanity and society as opposed to that of apartheid.

A Christian vision of man and human society to my mind means openness and communality as against the exclusivity and emphasis on the own as a characteristic of the apartheid ideology. In accordance of this view cultural identity is not an embarrassment but rather an opportunity, not a threat but rather the source for human unity. Relations with those outside the group do not destroy but rather enhance the own identity. Through the interaction of diversity, community is established the basis for a stable society. The openness towards others is at the same time the guarantee for freedom, peace and social justice, because it counters the greed and power-hunger which emanate from national exclusivity. (Van der Walt, 1993:52.)

In addition to these ethical values Professor Van der Walt's personal love, affinity and obligation towards black Africans have demonstrated his personal experience and approach to apartheid as a white Afrikaner.

\subsection{On Western dualism and secularism}

Besides white racism and apartheid, he also addressed Western dualism and secularism. These two worldviews are contrary to the biblical and reformational worldview. Professor Van der Walt did his Christian training in philosophy and theology which were deeply rooted in the Calvinist Christian reformational tradition. Calvinism formed the foundation of the Christian reformational tradition. This Christian reformational tradition in philosophy and theology shaped his life in a profound way. He used it to critique Western dualism and secularism, on the one hand, and to formulate a Christian reformational worldview and reformational philosophy of Christian higher education, on the other. Professor Van der Walt pursued his Christian scholarship in this area with great passion. He developed a legacy of Christian scholarship which promoted Christian reformational philosophy and theology in Africa. The bulk of his writings and books are concerned with this theme. Besides the numerous articles in various journals and monographs, the following books are important and worth mentioning: Anatomy of reformation: flashes and fragments of a reformational worldview (Van der Walt, 1991b); A Christian worldview and Christian higher education for Africa (Van 
der Walt, 1991a); The liberating message: a Christian worldview for Africa (Van der Walt, 1994); Transformed by the renewing of your mind: shaping a biblical worldview and a Christian perspective on scholarship (Van der Walt, 2001a); and Transforming power: challenging contemporary secular society (Van der Walt, 2007).

These works expose the devastating effects of Western dualism and secularism for Western Christianity and theories of society which are destructive and particularly dangerous for African Christianity and society.

\subsection{Western dualism}

Professor Van der Walt traced the origins of dualism to classical Greek philosophy. Christianity borrowed and used Greek dualism uncritically, especially the two-realm theory of reality, the "distinction between the profane (or secular) and the sacred (or holy)" (Van der Walt, 1994:109-110) and "the distinction between two levels of knowledge/ontological realms" of reality (Van der Walt, 1994:111). Dualism as a view of reality leads to a misguided distinction in creation, a confusion of structure and direction, and harbours detrimental consequences for the involvement of the Christian reformation in the (sinful) world (Van der Walt, 1994:109-114-116). Professor Van der Walt advocates a radical rejection of dualism.

Dualist Christian worldviews could be compared with a chronic disease which has paralyzed and crippled Christianity for two thousand years and robbed it of any energy to reform the world around it. It is such a dangerous enemy of Christianity, because most Christians are not even aware of the fact that they are infected with the virus. It has become the most natural thing for them to wear double-focus glasses and to see the whole of reality divided into secular and sacred domains. (Van der Walt, 1994:109-116-117.)

By way of solution, he suggests that Christians "get rid of their spectacles, their distorting worldview. It should be exchanged for a genuine Christian worldview which sees the whole reality as a place where we should serve and glorify God" (Van der Walt, 1994:117). A solution to Western dualism is a Christian worldview that defines religion as

... radical, total and integral. We do not serve God only in certain places, times and occasions, but we have to be everywhere and always in his service - irrespective of the type of work that we are doing. (Van der Walt, 1994:117.) 
He offers the following ways of correcting the dualist conception of reality: a systematic approach, clarifying the relationship between nature and grace or creation and redemption; a historical approach, situating the sovereign God's all-encompassing kingdom in its historical development - creation, fall, redemption and consummation; and a religious approach (concerned with structure and direction) (Van der Walt, 1994:109-110). This methodology serves two functions: it serves as a critique of Western dualism and secularism as well as a process of formulating a Christian reformational worldview and philosophy of Christian higher education.

In order to address the problem of dualism, Professor Van der Walt used a Christian theology, philosophy and social history, and the Holy Scriptures as foundation for a Christian reformational worldview and the philosophy of Christian higher education. His works in this area have challenged Christians in Africa to examine Western forms of Christianity that have been infected with dualism and secularism and to replace them with the Christian reformational worldview.

From most of the books mentioned above, it emerges that, with regard to this problem, the Christian reformational worldview and the philosophy of Christian higher education go hand in hand. Dualism and secularism could be combatted with the Christian reformational worldview and the philosophy of Christian higher education.

\subsection{Western secularism}

Many of the books mentioned above mention the problem of Western secularism, but Professor Van der Walt's recent publication, Transforming power: challenging contemporary secular society (Van der Walt, 2007), is dedicated to addressing the question of secularism exclusively. He picks out the popular themes of private and public religion in Western theological and religious discourse and describes the growth of private religion and the declining influence of religions in the public sphere. The public nature of religion is gradually being replaced by the new world religion, that is, secularism, which rules everywhere. In this book, he discusses "how to transform the increasingly secular culture and social life today" (Letšosa quoted in Van der Walt, 2007:vi). The devastating effect of secularism is not only felt in the West, but also in the nonWestern world.

There is an important aspect of secularism which I want to add to Professor Van der Walt's views in this area. The symbiotic relationship between classical Western culture and Christianity produced 
the following very important and influential social factors: the rising power and influence of advanced science and technology, democracy, and capitalism in the world; the fall of Western ethnocentrism (culture), colonialism and Christendom; the emergence of modern philosophies; and the revival of neo-paganism (Turaki, 2006:20-24). Western modern philosophies (secularism, pluralism, relativism and modernism) have contributed immensely to the fall of Western ethnocentrism and Christendom. Similarly, the rise of the forces of Western global civilisation (democracy, advanced science and technology and capitalism) has also become a modern tool for waging global religious and cultural wars that are weakening the influence of religion. However, I must add that there is a strong revival of neo-pagan religions in the West and in the non-Western world. These days we are seeing the revival of militant Islam in its confrontation with the West, especially the United States of America.

We observed that at the end of the nineteenth and early twentieth centuries, Western colonialism and ethnocentrism became weakened and eventually crumbled. Christendom was the first to fall long after Martin Luther's Protestant Reformation and the rise of nationstates in Europe. However, Christianity still dominated the religious and cultural life of Europe and the West in general. After the colonial era in the mid-twentieth century, both Western culture and Christianity shared the embarrassment and guilt of Western colonialism and the economic and political exploitation of the colonies. Christianity was not critical enough of the evils of colonialism and the economic and political exploitation of the colonies. In fact, it benefited from them (Son, 2001:10). The fall of colonialism also led to the fall of Western ethnocentrism (cultural superiority), especially through the works of cultural anthropologists who introduced pluralistic and relativistic views of culture and values (Son, 2001:10-11).

Modern philosophies have great power and influence in shaping, moulding, defining and conditioning the role and place of religion in Western society. Charles Colson describes the Western postmodernist mentality in the following words:

... today's culture not only is post-Christian but also is rapidly becoming postmodernist, which means it is resistant not only to Christian truth claims but to any truth claims. Postmodernism rejects any notion of a universal, overarching truth and reduces all ideas to social constructions shaped by class, gender, and ethnicity ... In postmodernism, there is no objective, universal truth; there is only the perspective of the group, whatever the 
group may be: African-Americans, women, gays, Hispanics, and the list goes on. In postmodernism, all viewpoints, all lifestyles, all beliefs and behaviors are regarded as equally valid. (Colson \& Pearcey, 1999:23.)

Given the power and influence of these modern philosophies (secularism, pluralism, relativism and postmodernism), religion has no central role to play in Western society. The place, role and status of religion in Western society have been relegated to the periphery. Son (2001:14-15) describes this change in the following words:

Unfortunately, however, the secularization process in the West has pushed the Christian faith as well as other related values also to the periphery. Art, literature, drama, music, etc., that have their origin in religious rites and enjoyed relatively high appreciation in the past, have all been pushed to the peripheries as luxuries of life, while money, physical force, political power, labour, and leisure have become the necessities of life and ascended to the center. The Enlightenment rationalism, development of natural science and technology, and the accompanying materialism and hedonism have deposed the faith that reigned on the cultural throne and usurped it.

\subsection{A comparative analysis of Western and African cultures}

Professor Van der Walt took the challenge posed by white racism and apartheid very seriously, all the while remaining sensitive to the fact that the African context is multi-ethnic/racial, multi-religious and multicultural. Africans, both whites and blacks, do misunderstand, misinterpret and misrepresent the cultures of the other. $\mathrm{He}$ addressed the issue of cultural diversity in Africa from a Christian perspective. The following of his works have been devoted to this subject: Cultural diversity in Africa: embarrassment or opportunity (1991c); Afrocentric or Eurocentric? Our task in a multicultural South Africa (1997); Culture, worldview and religion: a perspective from the African continent (2001b:23-38); Understanding and rebuilding Africa (2004); and When African and Western cultures meet: from confrontation to appreciation (2006).

These books promote a better understanding of cultures and identity between the whites and blacks in Africa. They also address the crisis of values and worldviews which affect both Christianity and African development. The transformation of Africa by the colonial powers and missionaries' activities has generated and accelerated many socio-political, cultural and religious changes and crises that need to be addressed. In his Preface to Professor Van der Walt's 
book (2006) Emmanuel Ayee listed many of the burning issues in Africa that the book deals with. These include poverty, development, globalisation, leadership styles, different ways of viewing reality, the inferior position of women and the crisis of agriculture.

I observed that the primary objective of Professor Van der Walt's comparative cultural analysis is to offer solutions for dealing with cultural tensions, prejudice, stereotyping and discrimination. The best approach to cultural understanding is to study and evaluate "cultures in the light of a Christian worldview and philosophy" (Van der Walt, 1997; 2006). Ayee states that Professor Van der Walt sees culture in a positive sense "as a God-given opportunity for mutual enrichment and empowerment" (Ayee quoted in Van der Walt, 2006). The comparative method of cultural studies aims to help both whites and blacks in Africa to see the strengths and weaknesses of each other's culture. This understanding will foster mutual respect and cultural enrichment.

\section{Conclusion}

This article does not claim to have done justice to Professor Van der Walt's corpus of Christian scholarship. I have selected merely some parts of what I consider to be the most important features of his contribution to Christian scholarship in Africa. I have stressed the point that Professor Van der Walt is a bridge builder in Africa, bridging the gap between the whites and blacks in Africa during the days of apartheid. He has left an enduring legacy of Christian scholarship in Africa which can be summarised as: addressing the issue of white racism, its ideology of apartheid, and its devastating effects upon both the blacks and whites; criticising Western dualism and secularism and offering solutions based on the Christian reformational worldview and the philosophy of Christian higher education; undertaking extensive comparative analyses of Western and African cultures and offering solutions on how to address issues of cultural diversity, conflict and harmony; examining the issue of the impact of Western colonialism, dualistic Christianity and secularism on African Christianity, cultures, African identity, underdevelopment and leadership; and proposing solutions to the problems of racism/ apartheid, dualism, secularism, crises of development, identity and cultures by formulating and using the Christian reformational worldview and the philosophy of Christian higher education.

Professor Bennie van der Walt, no doubt has built an enviable and enduring legacy of Christian scholarship in Africa. We thank God for giving us such a precious gift in the person of Professor Bennie van 
der Walt. We join his compatriots, friends and well-wishers in celebrating God's faithfulness in his life!

\section{List of references}

BAUM, R.C. 1977. Authority codes: the invariance hypothesis. Zeitschrift für Soziologie, 6(1):5-28.

COLSON, C. \& PEARCEY, N. 1999. How now shall we live? Wheaton: Tyndale.

MOTLHABI, M. 1972. Essays on black theology. Johannesburg: University Christian Movement.

MOTLHABI, M. 1980. The theory and practice of black resistance to apartheid: a social-ethical analysis of internal struggle for political and social change in South Africa, 1948-1978. Boston: Boston University Press. (Ph.D. dissertation.)

MOTLHABI, M. 1988. Challenge to apartheid: towards a moral national resistance. Grand Rapids: Eerdmans.

SON, B.H. 2001. Cultural relativism and the transformation of culture. Philisophia reformata, 66(1):9-22.

TURAKI, Y. 1992. An African response to the question of apartheid. Potchefstroom: IRS. (Series F1, no. 294.)

TURAKI, Y. 1999. Christianity and African gods. a method in theology. Potchestroom: IRS. (Series F2, no. 75.)

TURAKI, Y. 2006. African Christianity in global religious and cultural conflict. Nairobi: Evangelical Graduate School of Theology.

VAN DER WALT, B.J. 1988a. The Bible as eye-opener on the position of women. Potchefstroom: IRS. (Series F2, no. 44.)

VAN DER WALT, B.J. 1988b. On being human and being a Christian in Africa: communalism, socialism and communism in a struggle for an African anthropology. Potchefstroom: IRS. (Series F2, no. 42.)

VAN DER WALT, B.J. 1990. Being human: a gift and a duty - on the way to a Christian view of man for Africa. Potchefstroom: IRS. (Series F2, no. 42.)

VAN DER WALT, B.J. 1991a. A Christian worldview and Christian higher education for Africa. Potchefstroom: IRS.

VAN DER WALT, B.J. 1991b. Anatomy of reformation: flashes and fragments of a reformational worldview. Potchefstroom: IRS.

VAN DER WALT, B.J. 1991b. Cultural diversity in Africa: embarrassment or opportunity. Potchefstroom: IRS. (Series F3, no. 44.)

VAN DER WALT, B.J. 1993. Human dignity and identity: according to apartheid and according to the Word of God. (In Waijaki, M., Turaki, Y., Van der Walt, B.J. \& Kasenene, P. Visions of man and freedom in Africa. Potchefstroom: IRS. p. 29-52.) (Series F1, no. 302.)

VAN DER WALT, B.J. 1994. The liberating message: a Christian worldview for Africa. Potchefstroom: IRS. (Series F3, no. 44.)

VAN DER WALT, B.J. 1996. Responsibility, conversion, confession, forgiveness, restitution and reconciliation: six of God's requirements for a new South Africa. Potchefstroom: IRS. (Series F1, no. 337.)

VAN DER WALT, B.J. 1997. Afrocentric or Eurocentric? Our task in a multicultural South Africa. Potchefstroom: IRS. (Series F3, no. 67.) 
VAN DER WALT, B.J. 2001a. Transformed by the renewing of your mind: shaping a Biblical worldview and a Christian perspective on scholarship. Potchefstroom: ICCA.

VAN DER WALT, B.J. 2001b. Culture, worldview and religion: a perspective from the African continent. Philosophia reformata, 66(1):23-38.

VAN DER WALT, B.J. 2004. Understanding and rebuilding Africa. Potchefstroom: ICCA.

VAN DER WALT, B.J. 2006. When African and Western cultures meet: from confrontation to appreciation. Potchefstroom: ICCA.

VAN DER WALT, B.J. 2007. Transforming power: challenging contemporary secular society. Potchefstroom: ICCA.

\section{Key concepts:}

black Africans

Christian scholarship

philosophy of Christian higher education

reformational worldview

white Afrikaners

\section{Kernbegrippe:}

Christelike wetenskapsbeoefening

filosofie van Christelike hoëronderwys

reformatoriese wêreldbeskouing

swart Afrikane

wit Afrikaners 
